\title{
PERFORMANCE OF LAMBS FED RATIONS SUPPLEMENTED WITH THYME ESSENTIAL OIL
}

\author{
Soad El-Naggar ${ }^{* 1}$, G.A. Abou-Ward ${ }^{1}$, M.A. Tawila ${ }^{1}$,F.I.S.Helal ${ }^{1}$ and A.M. Ali ${ }^{2}$, \\ ${ }^{1}$ National Research Centre, Animal Production Department, Dokki, Giza, 12311, Giza, Egypt, \\ ${ }^{2}$ Cairo University, Animal Nutrition Department, Giza, 12613 Giza, Egypt \\ *Corresponding author E-mail: soadelnaggar75@gmail.com
}

(Received 8/6/2017, accepted 30/7/2017)

\section{SUMMMARY}

$\mathrm{E}$ ighteen growing Ossimi lambs (28.92 kg average live body weight and 6-7 months old) were used to evaluate incorporating thyme essential oil (TEO) in ration on nutrients digestibility and growth performance. In growth trial lasted 90 days followed by digestibility trial for 14 days, the lambs were randomly divided according to their live body weight into three feeding groups (6 each).Total mixed ration consisted of $60 \%$ concentrate: $40 \%$ roughage was offered to lambs in all groups to cover its total requirements. Whereas, there was no TEO in the control feeding group, R1, while R2 and R3 were supplemented with 0.1 and 0.2 TEO from DM intake, respectively. Data of nutrients digestibility indicated that incorporating TEO in both of R2 and R3 significantly $(\mathrm{P}<0.05)$ increased digestibility of DM, OM, CP, EE and NFE. While, EE digestibility was only significantly $(\mathrm{P}<0.05)$ increased in R3 compared with R1. The same trend was observed for nutritive value either as TDN or DCP, whereas it was significantly $(\mathrm{P}<0.05)$ improved with R2 and R3 compared with R1.There were no adverse effects for thyme oil supplementation on rumen $\mathrm{pH}$, but significant $(\mathrm{P}<0.05)$ decreased rumen ammonia concentration and increased the rumen volatile fatty acids compared with control group. As a result of this improvement in nutritive value, the highest body weight gains were recorded with R2 and R3 (187 and $200 \mathrm{~g} / \mathrm{h} / \mathrm{d}$ ) compared to $160 \mathrm{~g} / \mathrm{h} / \mathrm{d}$. for R1. So, it can be concluded that incorporating thyme essential oil in growing lambs ration by either 0.1 or $0.2 \%$ from $\mathrm{DM}$ intake improved both of nutrients digestibility and growth performance.

Keywords: Thyme essential oil, lambs, nutrients digestibility, growth performance.

\section{INTRODUCTION}

Plant essential oils (EO) are aromatic liquids extracted from plants through distillation and have many benefits as antimicrobial agents(Franz et al., 2010). Meanwhile, EO can be used instead of antibiotic in animal rations for health maintenance and improvement of animal performance. Whereas, since the beginning of using antibiotic as growth promoters in animal rations many reports on the emergence of resistance to some antibiotics in bacteria isolated from livestock were reported. So, there is a possibility of transferring that resistance to human pathogens through food chain arose (Dibner and Richards, 2005). World Health Organization (2016) reported that $61 \%$ of human pathogens are of animal origin. Some studies showed the potential of EO for fighting pathogenic bacteria (Zhang et al., 2016).

Thyme oil like the other essential oils has been shown antibacterial (Valero and Salmeroìn, 2003 and Elaissi et al., 2011), antioxidant (Cheel et al., 2005), antihyper-NH3-producing ruminal bacterial (McIntosh et al., 2003) and activities as well as the effects on changes of blood metabolites and rumen fermentation in Holstein steers (Hosoda et al., 2006) those will be led to an improvement in nutrients digestibility consequently, an improvement in growth performance will be expected.

So, the objective of this study was to determine the effects of thyme oil additive in growing lambs ration on intake, nutrients digestibility and growth performance. 


\section{El-Naggar et al.}

\section{MATERIALS AND METHODS}

\section{Preparation of experimental rations}

Basal total mixed ration contained almost $14 \% \mathrm{CP}$ and consisted of $40 \%$ wheat straw, $25.3 \%$ corn, $19.4 \%$ soyabean meal, $11.1 \%$ wheat bran, $1.7 \%$ minerals and vitamins mixture and $0.8 \%$ salts and $1.7 \%$ limestone was used as control ration (R1). The same ration was used with other two feeding groups but with addition of thyme oil by $0.1 \%(\mathrm{R} 2)$ and $0.2 \%(\mathrm{R} 3)$ from DM.

\section{Growth trial:}

Eighteen growing Ossimi lambs (28.92 kg average live body weight and 6-7 months old) were randomly divided by weight into three equal groups (6 each) in a growth trial lasted 90 days. Then, animal groups were randomly assigned to fed one of the experimental rations to cover its requirements according to NRC (1985), amounts of TMR were adjusted biweekly according to changes in live body weights. Clean drinking water was freely available at all times. Feed intakes were daily recorded; meanwhile, daily body weight gains and feed conversions ( $\mathrm{g}$ feed/g gain) were calculated biweekly.

\section{Digestibility trials:}

At the end of the feeding experiment, three animals from each experimental group was used in digestibility trials lasted 14 days;7 days were for adaptation and the other seven days for quantitative collection of feces and urine. Animals were individually dwelled in metabolic cages, where feces and urine were separately collected. Daily amounts of feed intake, feces and urine out-put were determined and daily recorded during the collection period. Samples represented tenth of the voided feces and excreted urine were taken daily just after collection. Urine samples were stored in tight bottles containing sulfuric acid (1:1) and refrigerated at $4^{\circ} \mathrm{C}$ for nitrogen determination. Feces samples were weighted and dried at $60^{\circ} \mathrm{C} / 12 \mathrm{hrs}$. in a hot oven. Dried samples of feces and feeds were ground to pass through $1-\mathrm{mm}$ sieve, and it was stored in emeried bottles for chemical analysis. Meanwhile, digestion coefficient and nutritive values of the experimental rations were calculated. Ruminal fluid samples were collected at the end of the digestibility trial via stomach tube before feeding then at 3 and $6 \mathrm{hrs}$. after feeding. Samples of rumen content, for each animal, were filtered through four layers of cheesecloth, and then ruminal $\mathrm{pH}$ was immediately recorded using digital $\mathrm{pH}$ meter then, samples were stored at $-20 \mathrm{C}$ for latter ammonia and volatile fatty acids analyses.

\section{Chemical analysis:}

Chemical composition of feeds and feces were determined for dry matter (DM), crude protein (CP), crude fiber (CF), ether extract (EE) and ash according to the standard methods of A.O.A.C. (2012). Nitrogen free extract (NFE) was calculated by difference. Urinary nitrogen (UN) was determined by the micro-kjeldahl method.). Concentration of rumen ammonia nitrogen was determined calorimetrically through a phenol-hypochlorite method according to Searle (1984). Rumen total volatile fatty acids (TVFA's) content was determined using a gas chromatograph (GC-2010, Shimadzu, Kyoto, Japan) equipped with a Flame Ionization Detector and a capillary column (HP-INNOWAX, 1909N-133, Agilent Technologies, Santa Clara, CA, USA), as described by Hu et al.(2005).

\section{Statistical analysis:}

Collected data concerning body weight gains, feed efficiency, nutrients digestibility and dietary nitrogen utilization were subjected to one way analysis of variance according to Steel and Torrie (1980) applying the general linear model procedure of SAS (2002), while, data of the rumen parameters were subjected to two-way analysis by the same previous procedure. Significant differences between means were calculated using Duncan's Multiple Range Test (1955).

\section{RESULTS AND DISCUSSION}

Data of chemical composition of the experimental rations in Table (1), mentioned that the growth requirements of growing lambs from crude protein and energy as recommended by NRC (1985) were offered.

Data in Table (2) showed that incorporating TEO in R2 and R3 significantly $(\mathrm{P}<0.05)$ increased the digestibility of DM, OM, CP, EE and NFE by (6.9 and 11.8\%), (6.4 and 9.8\%), (5.6 and 9.1\%), (8.3 and 
$10 \%$ ) and (7.2 and 9.1\%), respectively compared with R1. The improvement of CF digestibility was between R3 and R1 and non significant between R2 and R1. This improvement in nutrients digestion in R2 and R3 might be due to stimulatory effect of the sessional oil on digestion process in the rumen as mentioned by Burt (2004), Benchaar and Greathead (2011) and Cobellis et al., (2016) Carmen et al., (2017) that the major compounds identified in EO include monoterpene hydrocarbons (e.g.-pinene,phellandrene, p-cymene, m-cymene,-terpinene, and limonene) and phenolic compounds (e.g. carvacrol, thymol, and eugenol) leading to strong antimicrobial activities and presence of Eugenol, a phenolic compound, can inactivate some microbial enzymes. Both in vitro and in vivo studies have shown the capability of EO in affecting rate of digestion, VFA profiles, protein metabolism, the breakdown of plant cell wall materials and microbial populations (Cobelliset al..2016). the present results are in agreement with findings of Nanon et al.(2014) and Klevenhusen et al.(2015)that supplementation of EO in in-vitro trial tended to increase in vitro DM and organic matter disappearance compared with control. In the contrary, Wallace et al., (2002) and Hart et al., (2008) suggested that EO decreased degradation of readily degradable substrate, such as protein and starch, due to inhibition to colonization and digestion of these substrates by amylolytic and proteolytic bacteria. While, Vendramini et al.(2016). Abdallah et al., (2016) reported that addition of EO had no significant effect on total tract digestibility of dry matter, organic matter, crude protein and crude fiber.

Table (1). Chemical composition of the experimental rations.

\begin{tabular}{lc}
\hline Item & $\%$ \\
\hline Moisture & 09.44 \\
Dry matter composition (DM & \\
$\quad$ Organic matter (OM) & 93.90 \\
Crude protein (CP) & 13.59 \\
Crude fiber (CF) & 19.99 \\
Ether extract (EE) & 02.47 \\
Nitrogen free extract (NFE) & 57.85 \\
Ash & 06.10 \\
\hline
\end{tabular}

Table (2). Nutrients digestibility of the experimental rations.

\begin{tabular}{|c|c|c|c|c|}
\hline \multirow{2}{*}{ Item } & \multicolumn{3}{|c|}{ Experimental rations } & \multirow{2}{*}{$\pm \mathrm{SE}$} \\
\hline & $\mathrm{R} 1$ & $\mathrm{R} 2$ & $\mathrm{R} 3$ & \\
\hline \multicolumn{5}{|c|}{ Nutrients digestibility, $\%$} \\
\hline $\mathrm{DM}$ & $65.80^{\mathrm{b}}$ & $70.36^{\mathrm{a}}$ & $73.56^{\mathrm{a}}$ & 1.58 \\
\hline $\mathrm{OM}$ & $71.97^{\mathrm{b}}$ & $76.59^{\mathrm{a}}$ & $79.04^{\mathrm{a}}$ & 1.34 \\
\hline $\mathrm{CP}$ & $73.76^{\mathrm{b}}$ & $77.88^{\mathrm{a}}$ & $80.48^{\mathrm{a}}$ & 1.37 \\
\hline $\mathrm{EE}$ & $75.56^{\mathrm{b}}$ & $81.79^{\mathrm{a}}$ & $83.09^{\mathrm{a}}$ & 1.09 \\
\hline $\mathrm{CF}$ & $60.76^{b}$ & $63.19^{\mathrm{ab}}$ & $68.69^{a}$ & 1.45 \\
\hline NFE & $75.27^{\mathrm{b}}$ & $80.72^{\mathrm{a}}$ & $82.10^{\mathrm{a}}$ & 1.61 \\
\hline \multicolumn{5}{|l|}{ Nutritive value, $\%$} \\
\hline TDN & $69.92^{\mathrm{b}}$ & $74.45^{\mathrm{a}}$ & $77.42^{\mathrm{a}}$ & 2.07 \\
\hline DCP & $10.00^{\mathrm{b}}$ & $10.60^{\mathrm{a}}$ & $10.90^{\mathrm{a}}$ & 0.21 \\
\hline
\end{tabular}

$a, b, c \ldots . .$. Means with different superscripts in the same row differ significantly $(P<0.05)$.

The nutritive values of the experimental rations as TDN and DCP were significantly $(\mathrm{P}<0.05)$ improved with incorporating TEO in R2 being 74.45 and $10.60 \%$ and R3 being 77.42 and10.9\% compared with R1 being, 69.92 and $10.00 \%$, respectively. This result may be attributed to the improvements in the nutrients digestibility for R2 and R3.There were no adverse effects for R2 and R3 on sheep rumen parameters compared with R1 (Table 3). However, there was a significant $(\mathrm{P}<0.05)$ decrease in the mean rumen ammonia concentrations for R2 and R3 compared with R1 being, 15.88, 13.42 and $18.07 \mathrm{mg} / \mathrm{ml}$ $\mathrm{RL}$, respectively. This decrease in ruminal ammonia may be due to that TEO had antihyper- $\mathrm{NH}_{3}$ - 


\section{El-Naggar et al.}

producing ruminal bacterial activities effect (McIntosh et al., 2003). In the same context, Busquet et al., (2006) demonstrated that some EO (e.g., cinnamon oil, anise oil, clove bud oil, ginger oil, garlic oil, tea tree oil, and orengano oil) and their main components inhibited NH3-N concentration. But there was a significant $(\mathrm{P}<0.05)$ increase in the allover mean of rumen volatile fatty acids by 15.8 and $28 \%$, respectively for $\mathrm{R} 2$ and $\mathrm{R} 3$ compared with $\mathrm{R} 1$. This increase in ruminal VFA may be due to that rumen bacteria assimilate some of the released peptides and amino acids into microbial protein or ferment amino acids to produce VFA (Bach et al., 2005). These results accepted with findings of Klevenhusen et al.,(2015) that ruminal VFA concentration was increased by EO supplementation. However, there were insignificant differences among groups in the rumen $\mathrm{pH}$, this result agrees with findings of Lin et al.,

Table (3). Effect of feeding experimental rations on rumen parameters of sheep.

\begin{tabular}{|c|c|c|c|c|c|}
\hline \multirow{2}{*}{ Item. } & \multirow{2}{*}{$\begin{array}{c}\text { Sampling Time } \\
\text {,hr }\end{array}$} & \multicolumn{3}{|c|}{ Experimental rations } & \multirow{2}{*}{$\pm \mathrm{SE}$} \\
\hline & & R1 & $\mathrm{R} 2$ & R3 & \\
\hline \multirow{5}{*}{$\mathrm{pH}$} & 0 & 6.4 & 6.61 & 6.5 & \\
\hline & 3 & 5.4 & 5.61 & 5.5 & \\
\hline & 6 & 6.6 & 6.51 & 6.4 & \\
\hline & Mean & 6.13 & 6.24 & 6.13 & 0.16 \\
\hline & 0 & 15.82 & 13.10 & 11.80 & \\
\hline \multirow{3}{*}{$\mathrm{NH}_{3}-\mathrm{N}, 100 \mathrm{ml} \mathrm{RL}$} & 3 & 21.21 & 19.33 & 16.04 & \\
\hline & 6 & 17.18 & 15.19 & 12.41 & \\
\hline & Mean & $18.07^{\mathrm{a}}$ & $15.88^{\mathrm{b}}$ & $13.42^{\mathrm{c}}$ & 1.03 \\
\hline \multirow{4}{*}{ TVFA's meq/dl RL } & 0 & 9.7 & 11.67 & 13.67 & \\
\hline & 3 & 16.52 & 18.33 & 19.76 & \\
\hline & 6 & 11.35 & 13.48 & 14.67 & \\
\hline & Mean & $12.52^{\mathrm{c}}$ & $14.49^{\mathrm{b}}$ & $16.03^{\mathrm{a}}$ & 0.58 \\
\hline
\end{tabular}

$a, b, c \ldots . .$. Means with different superscripts in the same row differ significantly $(P<0.05)$.

(2013) who found no effect of essential oils on rumen $\mathrm{pH}$. Data of nitrogen balance utilization in Table (4) indicated that there was a significant $(\mathrm{P}<0.05)$ decrease in fecal nitrogen for sheep fed on R2 and R3

Table (4). Effect of feeding experimental rations on Feed intake, average body weight, feed efficiency and nitrogen utilization of sheep.

\begin{tabular}{lcccc}
\hline \multirow{2}{*}{ Item } & \multicolumn{3}{c}{ Experimental rations } & \multirow{2}{*}{ \pm SE } \\
\cline { 2 - 4 } & $\mathrm{R} 1$ & $\mathrm{R} 2$ & $\mathrm{R} 3$ & \\
\hline Initial BW, Kg & 29.75 & 28.63 & 28.38 & 1.92 \\
Final BW, Kg & $44.15^{\mathrm{b}}$ & $45.61^{\mathrm{a}}$ & $46.41^{\mathrm{a}}$ & 1.65 \\
Average daily gain, g & $160^{\mathrm{b}}$ & $187^{\mathrm{a}}$ & $200^{\mathrm{a}}$ & 12.5 \\
Daily intake, g & 1130 & 1100 & 1110 & \\
Feed efficiency, (Kg intake/Kg gain) & 7.1 & 5.9 & 5.6 & \\
Nitogen utilization & & & & \\
N intake, g/h/d & 31.84 & 32.49 & 33.47 & 1.62 \\
Fecal nitrogen, g/h/d & $8.34^{\mathrm{a}}$ & $7.19^{\mathrm{b}}$ & $6.52^{\mathrm{b}}$ & 0.48 \\
Urinary nitrogen, g/h/d & 15.20 & 15.63 & 15.60 & 1.33 \\
Nitrogen balance, g & $8.29^{\mathrm{b}}$ & $9.66^{\mathrm{ab}}$ & $11.34^{\mathrm{a}}$ & 0.92 \\
\hline
\end{tabular}

$a, b, c \ldots . .$. Means with different superscripts in the same row differ significantly $(P<0.05)$.

compared with those fed R1 being, 7.19, 6.52 and $8.34 \mathrm{~g}$, respectively and at the same time, there was no significant $(\mathrm{P}<0.05)$ difference in urinary nitrogen among groups. Meanwhile, there was a significant $(\mathrm{P}<0.05)$ increase in nitrogen balance for $\mathrm{R} 2$ and $\mathrm{R} 3$ compared with $\mathrm{R} 1$. This increase in nitrogen balance may be due to improvement of crude protein digestibility. Also, there was no significant difference among groups in the initial body weight, however, feeding lambs on rations contained TEO, R2 and R3, 
significantly $(\mathrm{P}<0.05)$ increased final body weight by 3.2 and $4.87 \%$ and average daily body weight gain by 14.44 and $20 \%$, respectively compared with those fed R1.These increases might be due to the high energy intake with R2 and R3 (818.9 and $859.4 \mathrm{~g}$ TDN/h/d.) compared to $790.1 \mathrm{~g} \mathrm{TDN} / \mathrm{h} / \mathrm{d}$. with R1, or it might be due to that TEO cause a reduction in rumen methane mitigation as a results of essential oils inhibited the energymeta- bolism of Streptococcus bovis and Selenomonas ruminantium (Evans and Martin, 2000) and the growth of Methanobrevi bactersmithii, a rumen Archaea (McIntosh et al.,2003), meanwhile, increasing energy availability for animals. This result agrees with findings of Haddad and Goussous (2005) Yang et al., (2010). The high feed efficiency (kg intake / kg gain) was recorded with R2 and R3 being, 5.9 and 5.6, respectively, compared to 7.1for R1.

\section{CONCLUSION}

From the previous results it could be concluded that incorporating thyme oil in growing lambs ration by either 0.1 or $0.2 \%$ from DM enhances feed utilization and growth performance without any adverse effects.

\section{REFERENCES}

Abdallah, M., M. Deml, C. Fahn and W. Windisch (2016). Effects of a Specific Blend of Essential Oil on Rumen Degradability, Total Tract Digestibility and Fermentation Characteristics in Rumen Fistulated Cows. J Dairy Vet Anim Res 2016, 3(2): 72.

A.O.A.C. (2012). Official Methods of Analysis of AOAC International, 19th Ed. Vol.1, "Animal feed". Maryland, USA, chapter 4:1-77.

Bach, A., S. Calsamiglia and M.D. Stern (2005). Nitrogen metabolism in the rumen. J. Dairy Sci. 88, 9.

Benchaar, C. and H. Greathead (2011). Essential oils and opportunities to mitigate enteric methane emissions from ruminants. Animal Feed Science and Technology166-167, 338.

Burt, S. (2004). Essential oils: their antibacterial properties and potential applications in foods-a review. Int. J. Food Microbiol. 94, 223.

Busquet, M., S. Calsamiglia, A. Ferret and C. Kamel (2006). Plant extracts affect in vitro rumen microbial fermentation. J. Dairy Sci. 89, 761.

Carmen, M.S.A., M.S. de Alencara, R.L.M. de Sousab, A.M. Morenoc and E.M. Da Gloriaa (2017).Antimicrobial activity of several essential oils on pathogenic andbeneficial bacteria. Industrial Crops and Products 97, 128.

Cheel, J., C. Theoduloz, J. Rodriìguez and G. Schmeda-Hirschmann (2005). Free radical scavengers and antioxidants from lemongrass (Cymbopogoncitratus (DC.) Stapf.). J. Agric. Food Chem. 53, 2511.

Cobellis, G., M.Trabalza-Marinucci andZ. Yu (2016). Critical evaluation of essential oils as rumen modifiers in ruminant nutrition: a review. Sci. Total Environ.545, 556.

Dibner, J.J. and J.D. Richards (2005). Antibiotic growth promoters in agriculture: history and mode of action. Poult. Sci. 84, 634.

Duncan, D.B. (1955). Multiple Range and Multiple (F-test). Biometrics, 11: 1-42.

Elaissi, A., K.H. Salah, S. Mabrouk, K.M. Larbi, R. Chemli and F. Harzallah-Skhiri (2011). Antibacterial activity and chemical composition of 20 Eucalyptus species'essential oils. Food Chem. 129, 1427.

Evans, J.D. and S.A. Martin (2000). Effects of thymol on ruminal micro-organisms. Curr. Microbiol. 41,336-340.

Franz, C., K.H.C. Baser and W. Windisch (2010). Essential oils and aromatic plants in animal feeding-a European perspective. A review. Flavour Fragr. J. 25 (5), 327.

Haddad, S.G. and S.N. Goussous (2005). Effect of yeast culture supplementation on nutrient intake, digestibility and growth performance of Awassi lambs. Anim. Feed Sci. and Tech., 118:343. 


\section{El-Naggar et al.}

Hart, K.J., D.R. Yanez-Ruiz, S.M. Duval, N.R. McEwan and C.J. Newbold (2008). Plant extracts to manipulate rumen fermentation. Animal Feed Science and Technology147, 8.

Hosoda, K., K. Kuramoto, B. Eruden, T. Nishida and S. Shioya (2006). The effects of three herbs as feed supplements on blood metabolites, hormones, antioxidant activity, IgG concentration, and ruminal fermentation in Holstein steers. Asian-Australas. J. Anim. Sci. 19, 35.

Hu, W.L.,J.X. Liu, J.A. Ye, Y.M. Wu, and Y.Q.Guo (2005). Effect of tea saponin on rumen fermentation in vitro. Anim. Feed Sci. Technol. 120, 333.

Klevenhusen, F. D.t K., Ö. Sizmaz, S. Wimmer, A. Muro-Reyes, R. Khiaosa-Ard, R. Chizzolaand Q. Zebeli (2015). Effects of black seed oil and Ferula elaeochytris supplementation on ruminal fermentation as tested in vitro with the rumen simulation technique (Rusitec)Anim Prod Sci http://dx.doi.org/10.1071/AN13332.

Lin, B. B., Y. Lua, A.Z.M. Salemc, J.H. Wanga, Q. Lianga and J.X. Liu (2013). Effects of essential oil combinations on sheep ruminal fermentation and digestibility of a diet with fumarate included. Animal Feed Science and Technology 184, 24.

McIntosh, F.M., P.Williams, R. Losa, R.J. Wallace, D.A. Beever and C.J. Newbold (2003). Effect of essential oil on ruminal metabolism and their proteinmetabolism. Appl. Environ. Microbiol. 69, 5011.

Nanon, A., W. Suksombata and W.Z. Yang (2014). Effects of essential oils supplementation on in vitro and in situ feed digestion in beef cattle. Animal Feed Science and Technology 196, 50.

NRC (1985). Nutrient requirements of sheep. Sixth revised edition, National academy press, Washington, DC.

SAS (2002). Statistical Analysis Systems (SAS) Institute Inc., 2002. SAS/ STAT. User.

Searle, L.P. (1984). The berthelot or indophenol reaction and its use in the analytical chemistry of nitrogen: a review. Analyst 109, 549.

Steel, R.G.D. and J.H. Torrie (1980). Principles and Proceduresof Statistics. A biometrical approach. $2^{\text {nd }}$ edition. McGraw-Hill, New York, USA, pp. 20-90.

Valero, M. and M.C. Salmeroìn (2003). Antibacterial activity of 11 essential oils against Bacillus cereus in tyndallized carrot broth. Int. J. Food Microbiol. 85,73.

Vendramini, T.H.A. , C.S. Takiya, T.H. Silva, F. Zanferari, M.F. Rentas, J.C. Bertonia, C.E.C. Consentinia, R. Gardinala, T.S. Acedob and F.P. Rennóa (2016). Effects of a blend of essentials oils, chitosan or monensin onnutrient intakeand digestibility of lactating dairy cows.Animal Feed Science and Technology http://dx.doi.org/10.1016/j.anifeedsci.2016.01.015

Wallace, R.J., N.R. McEwan, F.M. McIntosh, B. Teferedegne and C.J. Newbold, (2002). Natural products as manipulators of rumen fermentation. Asian Austral. J. Anim. 15, 1458.

World Health Organization, (2016). Zoonoses: The Control of Neglected Zoonotic Diseases [online]. Accesed 20 July 2016. Avaliable from: http://www.who.int/zoonoses/control neglected zoonoses/en/.

Yang, W. Z., B. N. Ametaj, M. L. He, C. Benchaar, and K. A. Beauchemin. (2010). Cinnamaldehyde in feedlot cattle diets: intake, growth performance, carcass characteristics, and blood metabolites. J. Anim. Sci. 88:1082.

Zhang, Y., X. Liu, Y. Wang, P. Jiang and S. Quek (2016). Antibacterial activity and mechanism of cinnamon essential oil against Escherichia coli and Staphylococcus aureus. Food Control 59, 282. 


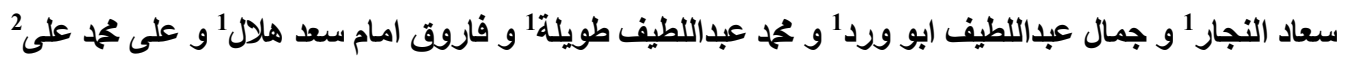

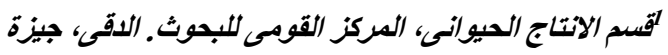

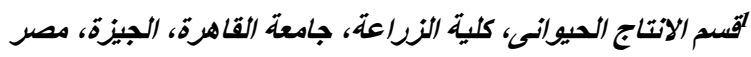

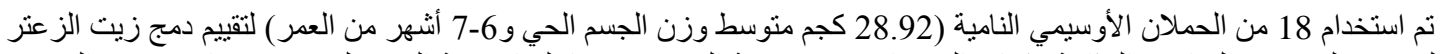

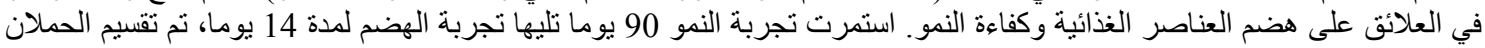

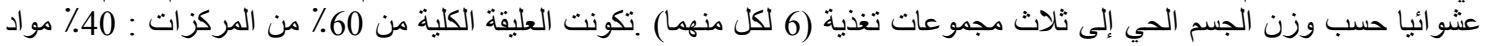

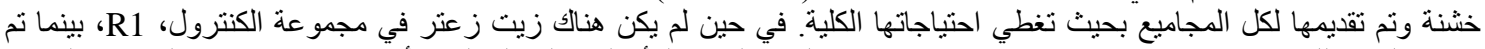

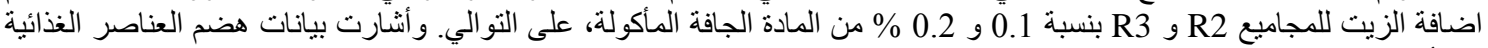

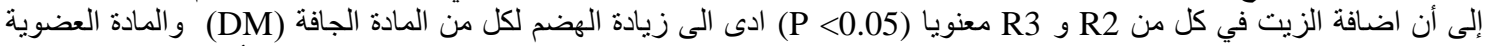

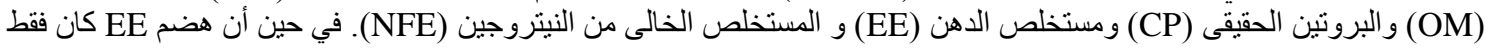

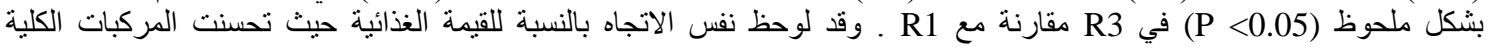

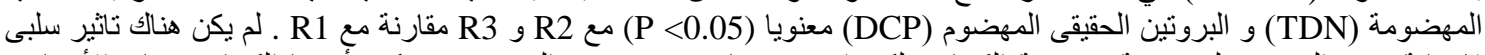

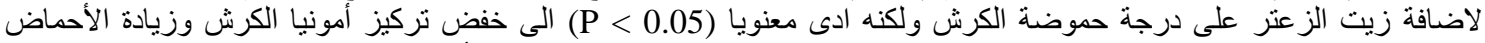

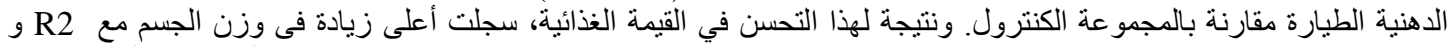

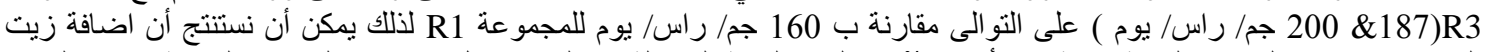

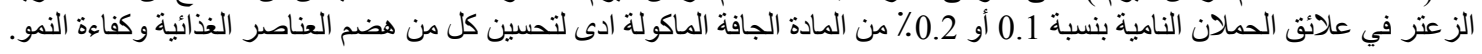

كلمات مفتاحية: زيت الزعتر ، الحملان،هضم العناصر الغذائية وكفاءة النمو 